Journal of Engineering Sciences, Assiut University, Vol. 38, No. 3, pp.697-715, May 2010.

\title{
DESIGN OF DOMESTIC OIL SHALE FURNACE SYSTEM
}

\section{Mohammed Awwad Al-Dabbas}

Assistance professor, Mechanical Engineering department, Mutah

University, Karak, Jordan.

madabbas@mutah.edu.jo, madabbas@yahoo.com

(Received February 20, 2010 Accepted March 31, 2010).

Furnaces of steel sheet combustion chamber were designed, constructed and operated to burn oil shale. The constructed combustion chamber was operated satisfactorily for several hours of operation.

The experiments were conducted at steady state conditions using different values of air fuel ratios. High combustion efficiencies were achieved at various operating condition. The combustion efficiency was noticed to increase with the increase of air to fuel ratio for each test. Carbon monoxide concentration in flue gas was found to decrease with the increase in air fuel ratio. This was associated with the decrease in oxygen gas and an increase in carbon dioxide.

During experimental work chromel-alumel thermocouples were used to measure the temperature distribution within the flame. Exhaust gases were analyzed using (motor scan gas analyzer 8070).

Concentrations of $\mathrm{CO}, \mathrm{CO}_{2}$ and $\mathrm{O}_{2}$ in the flue gas were measured under various operating conditions. Carbon residue after burning was collected and analyzed.

KEYWORD: oil shale, furnace, gas emission, temperature distribution, factor of safety, domestic, combustion efficiency

\section{NOMENCLATURE}

A: sum of surface area of tube, area of $\dot{m}_{\mathrm{f}}$ : mass flow rate of fuel $(\mathrm{Kg} / \mathrm{s})$

shear, area of surface body of surface, area of surface body of furnace $\left(=5.415 \mathrm{~m}^{2}\right)\left(\mathrm{m}^{2}\right)$

$\mathrm{A}_{\mathrm{o}}$ : $\quad$ outside surface area per unit length $\left(\mathrm{m}^{2} / \mathrm{m}\right)$

$\dot{m}_{\mathrm{w}}$ : mass flow rate of water $(\mathrm{kg} / \mathrm{s})$

$\dot{m}_{\mathrm{r}}: \quad$ mass flow rate of ash $(\mathrm{kg} / \mathrm{s})$

$\mathrm{Q}_{\mathrm{R}}$ : the load input in furnace $(\mathrm{kW})$

$\mathrm{A}_{\mathrm{i}}: \quad$ inside surface area per unit length $\left(\mathrm{m}^{2} / \mathrm{m}\right)$

$\mathrm{t}: \quad$ thickness of tubes $(\mathrm{m})$

$\mathrm{A}_{\mathrm{m}}: \quad \log$ mean area of tube $[=0.5$ $\left.\left(\mathrm{A}_{\mathrm{o}}+\mathrm{A}_{\mathrm{i}}\right)\right]\left(\mathrm{m}^{2}\right)$

$\mathrm{T}_{\mathrm{s}}$ : $\quad$ surface temperature of furnace $\left(=558^{\circ} \mathrm{C}\right)$

b: width $(\mathrm{m})$

$\mathrm{C}_{\mathrm{o} 2}$ percentage of carbon in flue gases $(=8.62 \%)$

$\mathrm{C}_{\mathrm{V}}$ : calorific value of oil shale $(\mathrm{kJ} / \mathrm{kg})$

$\left(\mathrm{T}_{\mathrm{o}}-\mathrm{T}_{\mathrm{i}}\right)$ : difference between outlet and inlet temperature for flue gases $\left({ }^{\circ} \mathrm{C}\right)$

$\left(\mathrm{T}_{\mathrm{o}}-\mathrm{T}_{\mathrm{i}}\right)$ : water temperature different between outlet \& inlet to the boiler

$\mathrm{T}_{\mathrm{o}}$ : temperature of out air $\left(=20{ }^{\circ} \mathrm{C}\right)$ 


\begin{tabular}{|c|c|c|}
\hline & welded fitting $(\mathrm{m})$ & $\begin{aligned} \mathrm{T}_{\mathrm{s}}= & \text { absolute surface temperature of } \\
& \text { furnace }(\mathrm{K})\end{aligned}$ \\
\hline E: & modulus of elasticity & $\begin{array}{l}\mathrm{T}_{\mathrm{o}} \text { : the temperature outlet of the heat } \\
\text { exchanger }\left({ }^{\circ} \mathrm{C}\right)\end{array}$ \\
\hline h: & the leg size $(\mathrm{m})$ & $\begin{array}{l}\mathrm{T}_{\mathrm{i}}: \quad \text { the temperature inlet to the heat } \\
\text { exchanger }\left({ }^{\circ} \mathrm{C}\right)\end{array}$ \\
\hline h: & $\begin{array}{l}\text { heat transfer coefficient }(=15 \\
\left.\mathrm{W} / \mathrm{m}^{2} . \mathrm{K}\right)\end{array}$ & $\begin{array}{l}\text { the overall heat transfer coefficient } \\
\left(\mathrm{W} / \mathrm{m}^{2} . \mathrm{K}\right)\end{array}$ \\
\hline $\mathrm{h}_{\mathrm{i}}:$ & $\begin{array}{l}\text { heat transfer coefficient inside tubes } \\
\left(\mathrm{W} / \mathrm{m}^{2} .{ }^{\circ} \mathrm{C}\right)\end{array}$ & $\begin{array}{l}\mathrm{U}: \quad \text { internal energy of ash }\left(\mathrm{W} / \mathrm{m}^{2} . \mathrm{K}\right) \\
\mathrm{V}: \quad \text { shear force }(\mathrm{N})\end{array}$ \\
\hline$h_{0}:$ & $\begin{array}{l}\text { heat transfer coefficient of fluid } \\
\text { outside tubes }\left(\mathrm{W} / \mathrm{m}^{2} .{ }^{\circ} \mathrm{C}\right)\end{array}$ & $\bar{v}:$ average velocity $(\mathrm{m} / \mathrm{s})$ \\
\hline & $\begin{array}{l}\text { in: Enthalpy outlet at inlet temperature } \\
\text { of water }(\mathrm{kJ} / \mathrm{kg})\end{array}$ & $\varepsilon: \quad$ strain \\
\hline K: & $\begin{array}{l}\text { coefficient for emission from solid } \\
\text { fuel }(=0.002)\end{array}$ & $\alpha:$ specific thermal expansion \\
\hline $\mathrm{k}:$ & $\begin{array}{l}\text { thermal conductivity of tube } \\
\text { material }(\mathrm{W} / \mathrm{m} . \mathrm{K})\end{array}$ & $\begin{array}{l}\text { emissivity of the surface ( } 1 \text { for } \\
\text { black body) }\end{array}$ \\
\hline$\dot{m}$ & mass flow rate of flue gases $(\mathrm{kg} / \mathrm{s})$ & the density of flue gas $\left(\mathrm{kg} / \mathrm{m}^{3}\right)$ \\
\hline
\end{tabular}

\section{INTRODUCTION}

Jordan's energy sector will go under major modernization in the coming 10-15 years, with the approval of Jordan's Energy Master Plan by the cabinet, which will inject about $\$ 3$ billion of public and private sector capital [1-6].

This plan will cover all the activities of the sector from the exploitations of natural resources to electricity tariff levels, including energy demand, power sector development, gas distribution, oil refining and renewable energy and especially oil shale

Oil shale as shown in figure 2 is diverse fine-grained rocks, which contain refractory organic material that can be refined into fuels. Soluble bitumen fraction constitutes about $20 \%$ of this organic material, whereas the remainder exists as an insoluble kerogen. All oil shale appear to have been deposited in shallow lakes, marshes, or seas, which supported a dense algal biota. The latter was a probable source for the shale-bound organic fuel precursors.

Oil shale is considered mainly as a source of raw material of fossil origin for energy production having a high content of ballast material, this being the reason why oil shale has seldom been employed as an alternative fuel in the past.

Figure 5 shows oil shale locations in Jordan, while table 2 shows the major mineral components of the Jordanian oil shale:

The following are the main localities of oil shale (Fig. 1): 


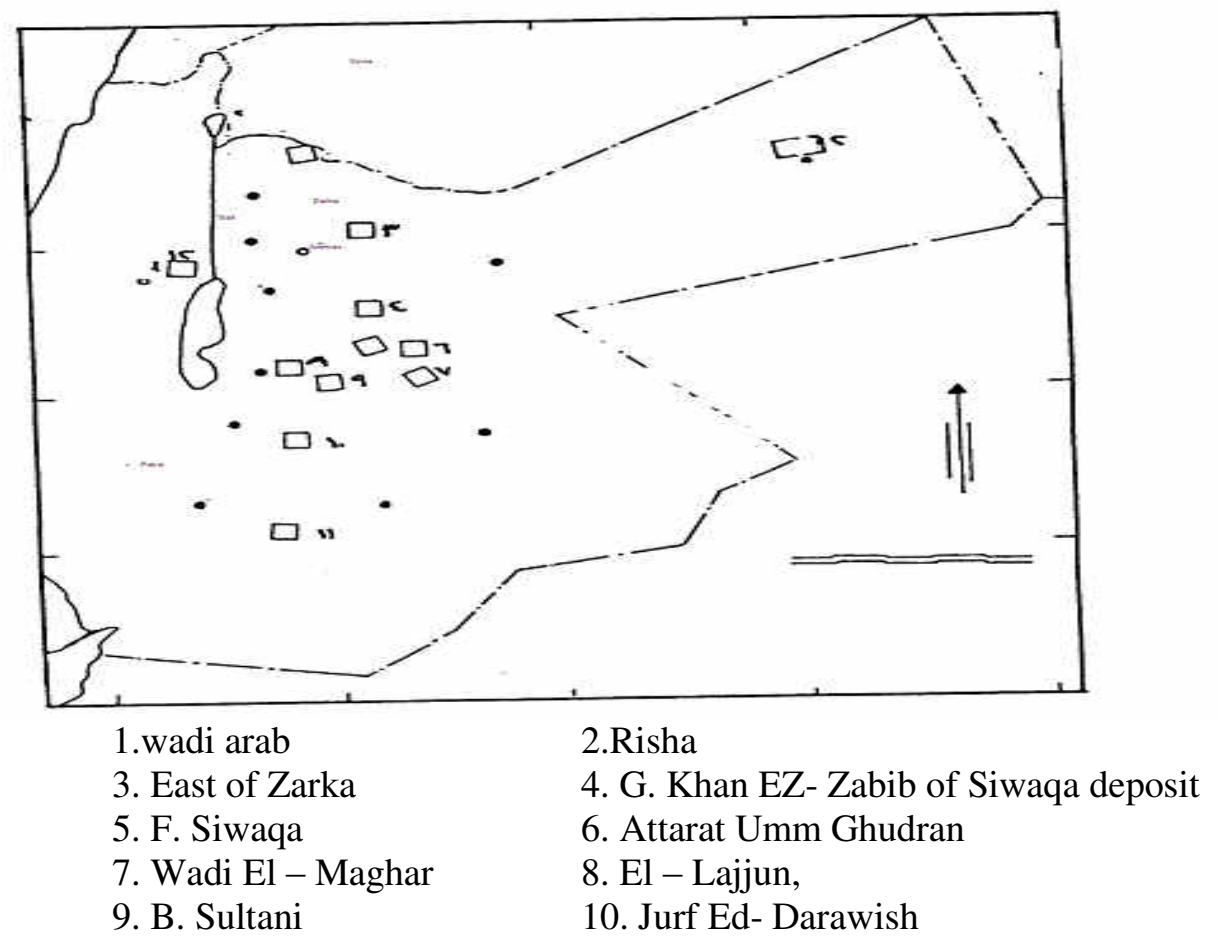

Figure 1: Oil shale location in Jordan.

A representative sample of El-Sultani oil shale deposit was provided by Ministry of Energy in Jordan. The approximate and ultimate analyses of the oil shale are given in table 2, and 3. The total oil percent was determined following the Fischer assay method. The calorific value was obtained by using Bomb Calorimeter

Table 1: The major mineral components of the Jordanian oil shale

\begin{tabular}{|l|l|l|}
\hline Silica & $\mathrm{SiO} 2$ & 15.1 \\
\hline Titanium oxide & $\mathrm{TiO} 2$ & 0.2 \\
\hline Aluminum oxide & $\mathrm{A} 2 \mathrm{O} 3$ & 2.64 \\
\hline Iron oxide & $\mathrm{Fe} 2 \mathrm{O} 3$ & 1.2 \\
\hline Magnesium oxide & $\mathrm{MgO}$ & 1.46 \\
\hline Calcium oxide & $\mathrm{CaO}$ & 32 \\
\hline Sodium oxide & $\mathrm{Na} 2 \mathrm{O}$ & 0.07 \\
\hline Carbon dioxide & $\mathrm{CO} 2$ & 0.06 \\
\hline Carbonate & $\mathrm{CO} 3$ & $15-20$ \\
\hline Phosphorus oxide & $\mathrm{P} 2 \mathrm{O} 5$ & 2.24 \\
\hline sulfur & $\mathrm{S}$ & $2-3$ \\
\hline Organic matter & $\mathrm{Organic}$ Matter & 25 \\
\hline Ash & $\mathrm{Ash}$ & 55 \\
\hline Humidity & $\mathrm{H} 2 \mathrm{O}$ & 4 \\
\hline Carbon dioxide (After burning) & $\mathrm{CO} 2$ & 19 \\
\hline Hydrogen & $\mathrm{H} 2$ & 1.6 \\
\hline Oxygen & $\mathrm{O} 2$ & 1.9 \\
\hline
\end{tabular}


Table 2: Properties of El-Sultani oil shale

\begin{tabular}{|c|c|}
\hline \multicolumn{2}{|c|}{ Proximate analysis, wt\% (as received) } \\
\hline Moisture & 0.46 \\
\hline Ash & 57.49 \\
\hline Volatile matter & 41.2 \\
\hline Fixed carbon & 0.85 \\
\hline \multicolumn{2}{|c|}{ Total $=100 \%$} \\
\hline \multicolumn{2}{|c|}{ Ultimate analysis, wt\% (as received) } \\
\hline Ash & 61.78 \\
\hline Fixed carbon & 0.85 \\
\hline Organic carbon wt & 14.91 \\
\hline Inorganic carbon & 3.81 \\
\hline Hydrogen & 1.93 \\
\hline Sulfur & 3.66 \\
\hline $\mathrm{CO} 2$, wt \% & 14.11 \\
\hline \multicolumn{2}{|c|}{ Total $=100 \%$} \\
\hline Total oil wt\% & 12.6 \\
\hline Particle density, $\mathrm{kg} / \mathrm{m}^{3}$ & 1800.0 \\
\hline Heating value, $\mathrm{kJ} / \mathrm{kg}$ & 7327.0 \\
\hline
\end{tabular}

Figures (2-4) show photographic of oil shale deposits in Jordan as shows in figures (6-10).

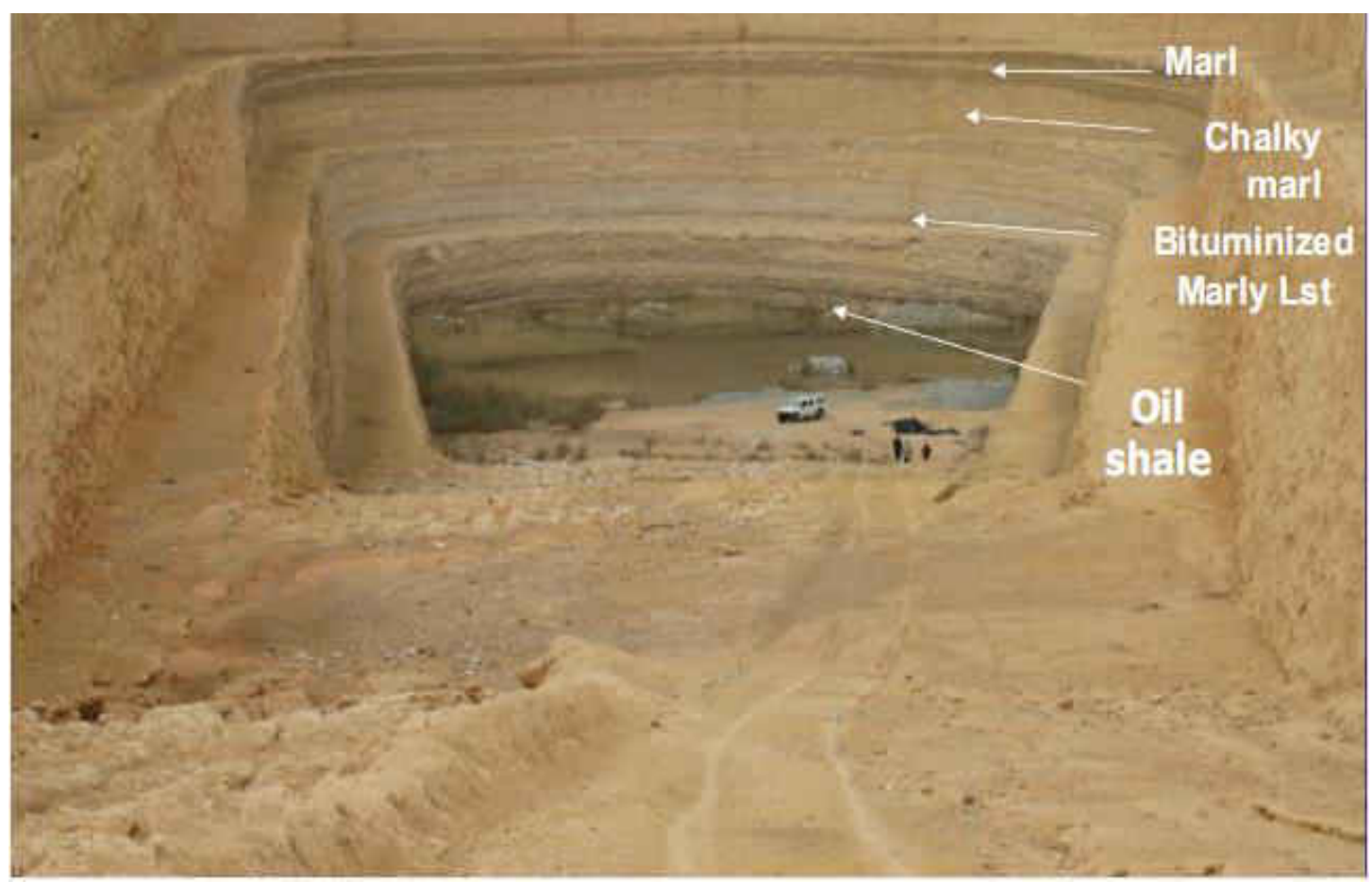




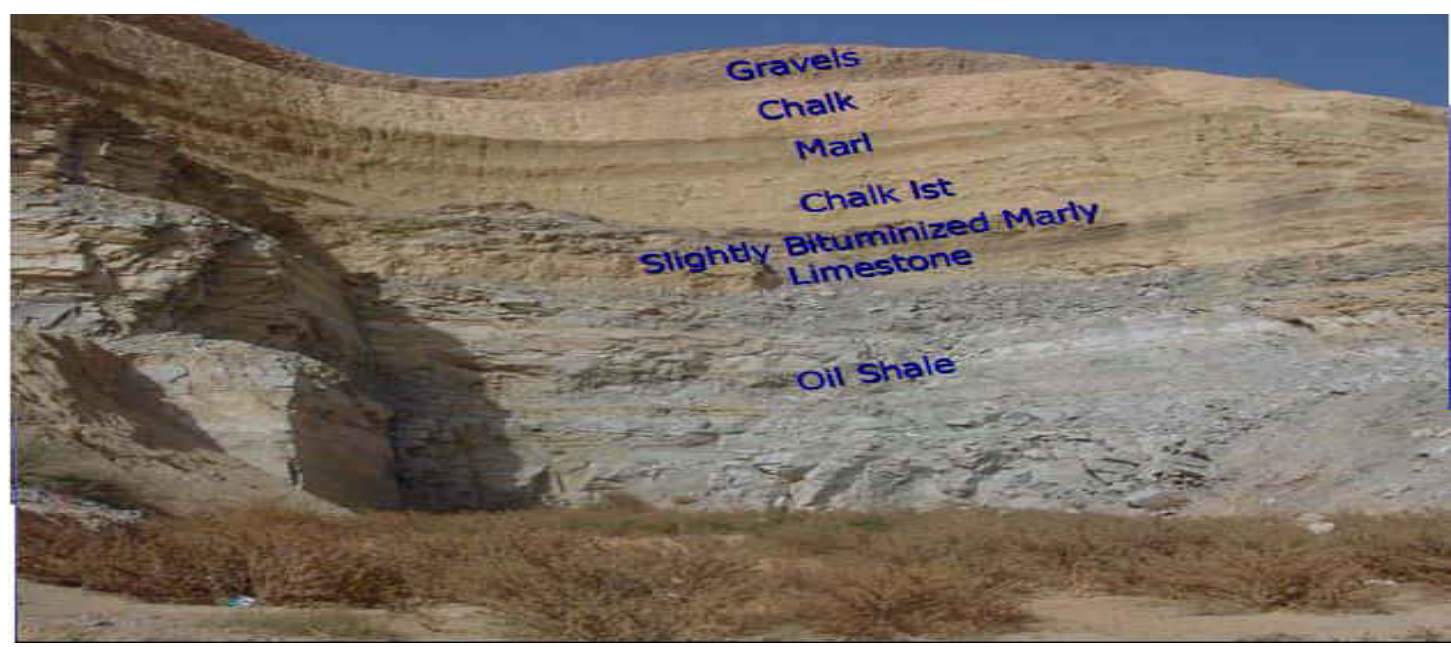

Figure 3: Over burden section of Lajjun

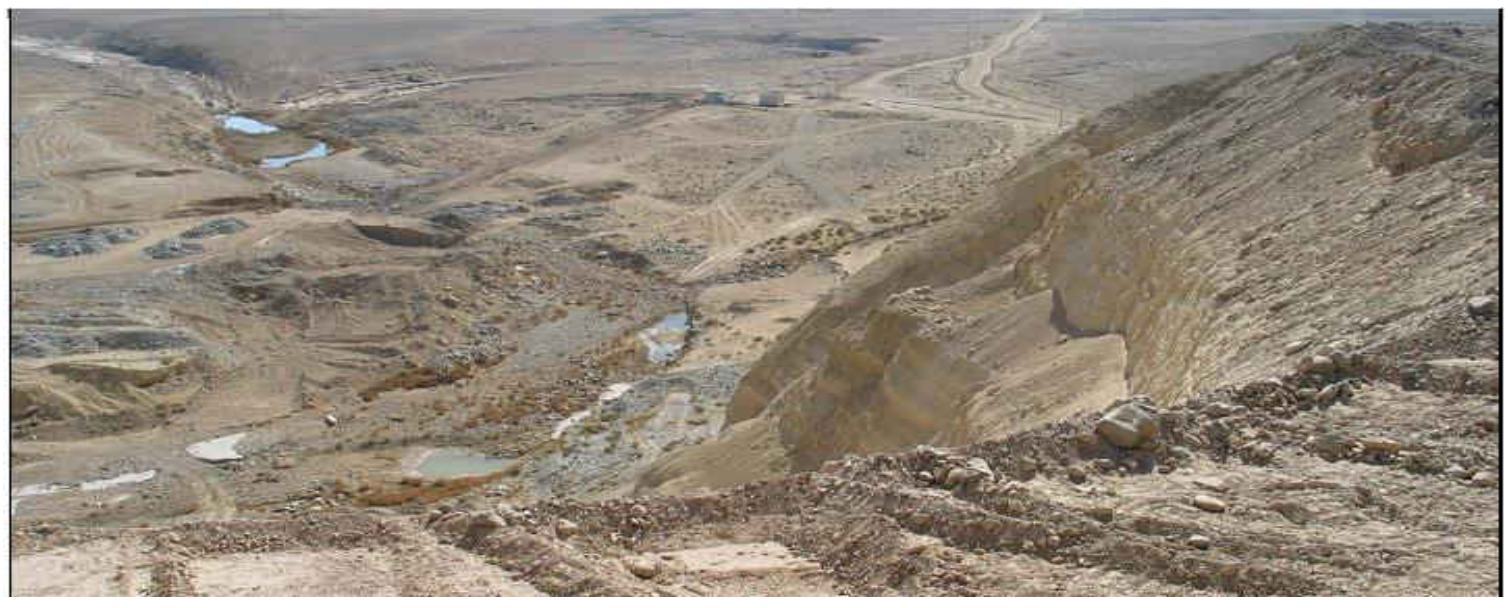

Figure 4: General view of ElLajjun

\section{OIL SHALE APPLICATION}

Oil shale can be used for several purposes: to obtain heat by direct combustion (for example, in the generation of electricity); to produce shale oil (SO); and as a source of other valuable chemicals. For example, from 1 tone of Estonian oil shale it is possible to produce $850 \mathrm{kWh}$ of electricity or $125 \mathrm{~kg}$ of shale oil $(39800 \mathrm{~kJ} / \mathrm{kg})$ and $35 \mathrm{~m}^{3}$ of retort gas $\left(46800 \mathrm{~kJ} / \mathrm{m}^{3}\right)$. The efficiency of new FBC (fluidized bed combustion) boilers is on the same level as has been reached in the best condensation atmospheric pressure power plants based on the combustion of coal -35-36\% (net).

Oil shale in Jordan:

The thermal processing of oil shale to oil has quite a long history and various facilities and technologies have been used as shown in figure 5 and figure 6 . In principle, there are two ways of the thermal processing: 
- low-temperature processing by heating the oil shale up to about $500^{\circ} \mathrm{c}-$ semicoking or retorting.

- high-temperature processing by heating up to $1000^{\circ} \mathrm{c}-1200^{\circ} \mathrm{c}-$ coking.

The technology of processing oil shale:

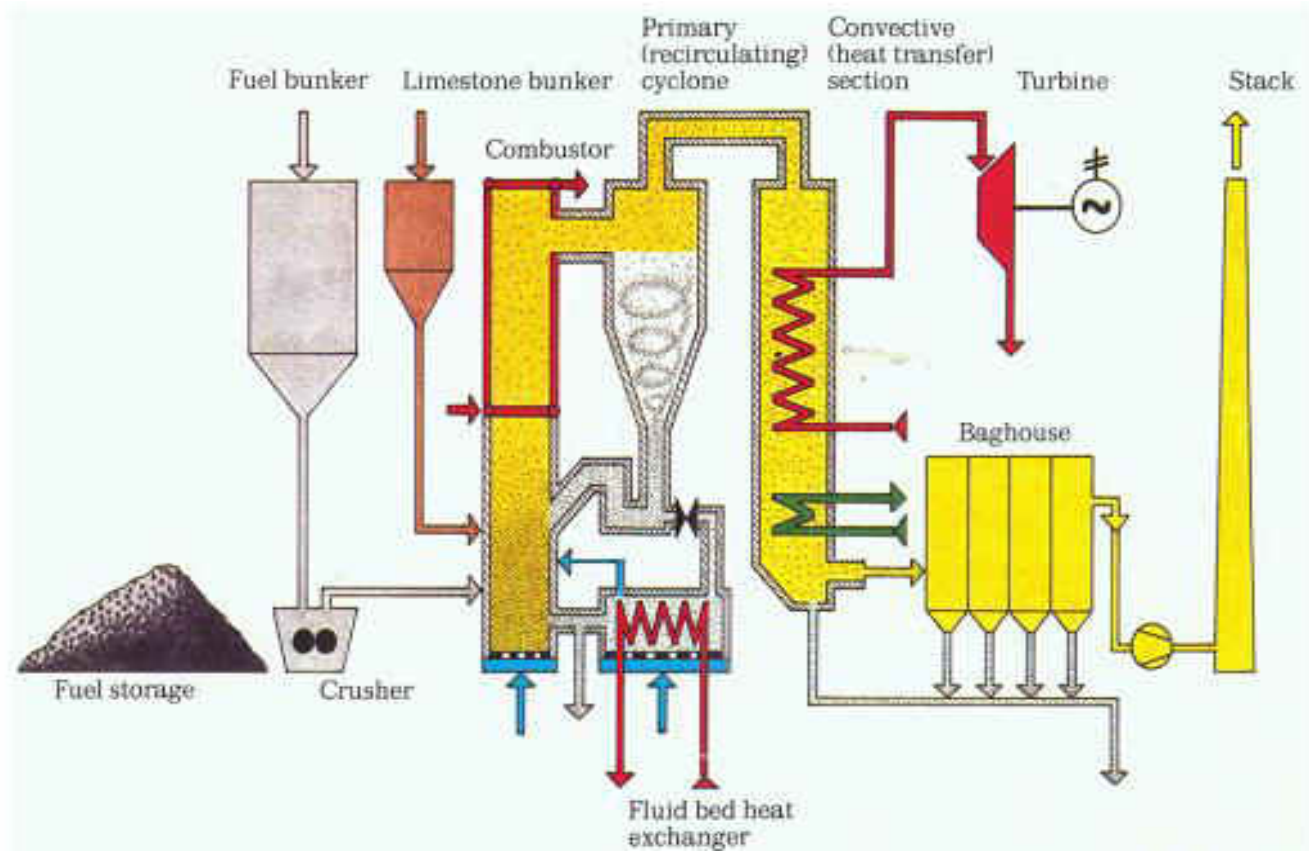

Figure 5 : fluidized bed system for oil shale burning

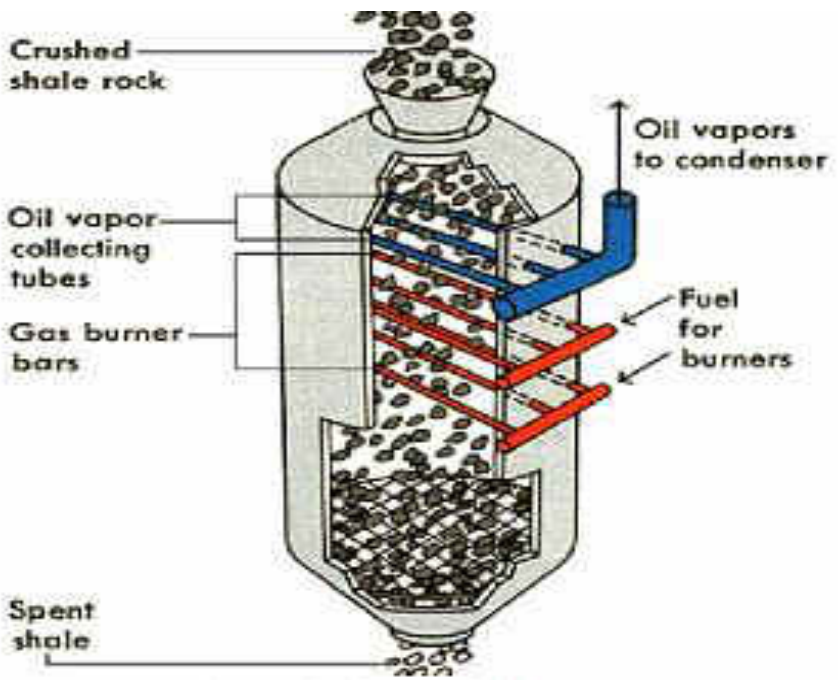

Figure 6: Oil Shale retorting system 
Although Jordanian oil shale was used already during the World War1, intensive exploration of the Jordan's oil shale took place only in the 1970s and 1980s. As of 2008, there is no oil shale industry in Jordan; however, several companies are planning to start shale oil extraction as also oil shale combustion for a power generation.

- The Jordanian oil shale is marinated of Late to early Tertiary age. It is typically brown, gray, or black and weather to a light bluish-gray.

- In general Jordanian oil shale is high quality comparable to the western United States oil shale, although their sulfur content is usually high.

- While the sulfur content of the most of oil shale in Jordan varies from 0.3 to $4.3 \%$ and the Sultani deposits have sulfur content of 8 to $10 \%$.

- Sulfur is mostly associated with the organic matter with minor occurrence as pyrite.

\section{Water Tube Furnace Design}

A water-tube boiler is a type of boiler in which water circulates in tubes heated externally by the fire as shown in figure 13 . Water-tube boilers are used for highpressure boilers. Fuel is burned inside the furnace, creating hot gas which heats up water in the tubes. In smaller boilers, additional generating tubes are separate in the furnace, while larger utility boilers rely on the water-filled tubes that make up the walls of the furnace to heat water.
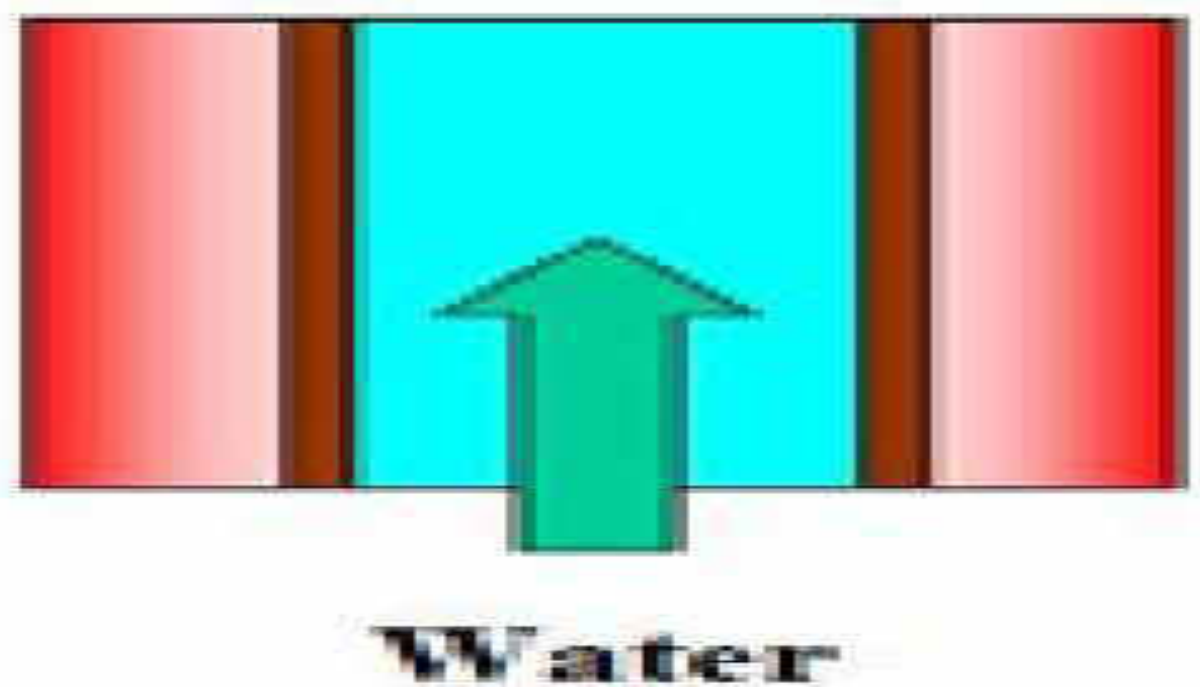

Figure 7: water-tube boiler

\section{System Analysis}

Figure 14 shows schematic diagram of residence, the heat load characteristic of this residence are:

- Total area=130 $\mathrm{m}^{2}$

- The total heat loss from all room in residence $=10.9 \mathrm{KW}$ 
- Load for furnace $=10.9 \mathrm{KW}$ at least

- Take safety factors $10 \%$ for emergency

- The furnace is designed for the domestic hot water.

\section{Design Requirements:}

Figure 8 shows the three side view of water -tube network inside the furnace.

1) Dimension :

Furnace: $\begin{array}{ll}\text { depth }=100 \mathrm{~cm} \quad, \quad D_{\text {chimney }}=16.7 \mathrm{~cm} \\ \text { Width }=100 \mathrm{~cm} \\ \text { Height }=100 \mathrm{~cm}\end{array}$
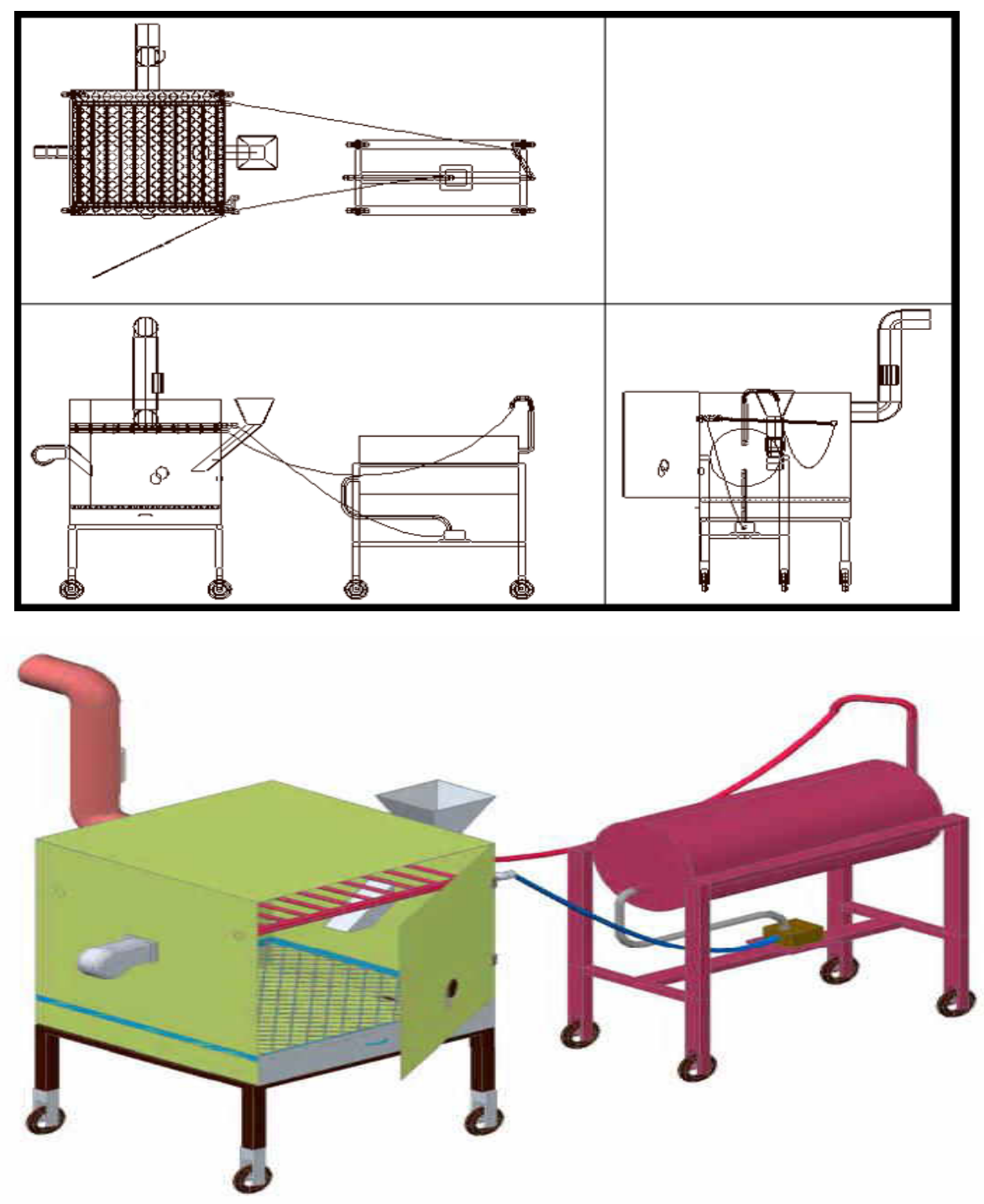

Figure1 8: Three side view of furnace. 


\section{Water Tube Network :}

Figure 9 shows the water tube network dimensions.

Two tube $(1.5 \mathrm{inch})$, length $=100 \mathrm{~cm}$

Eleven tube $(0.75 \mathrm{inch})$, length $=75 \mathrm{~cm}$

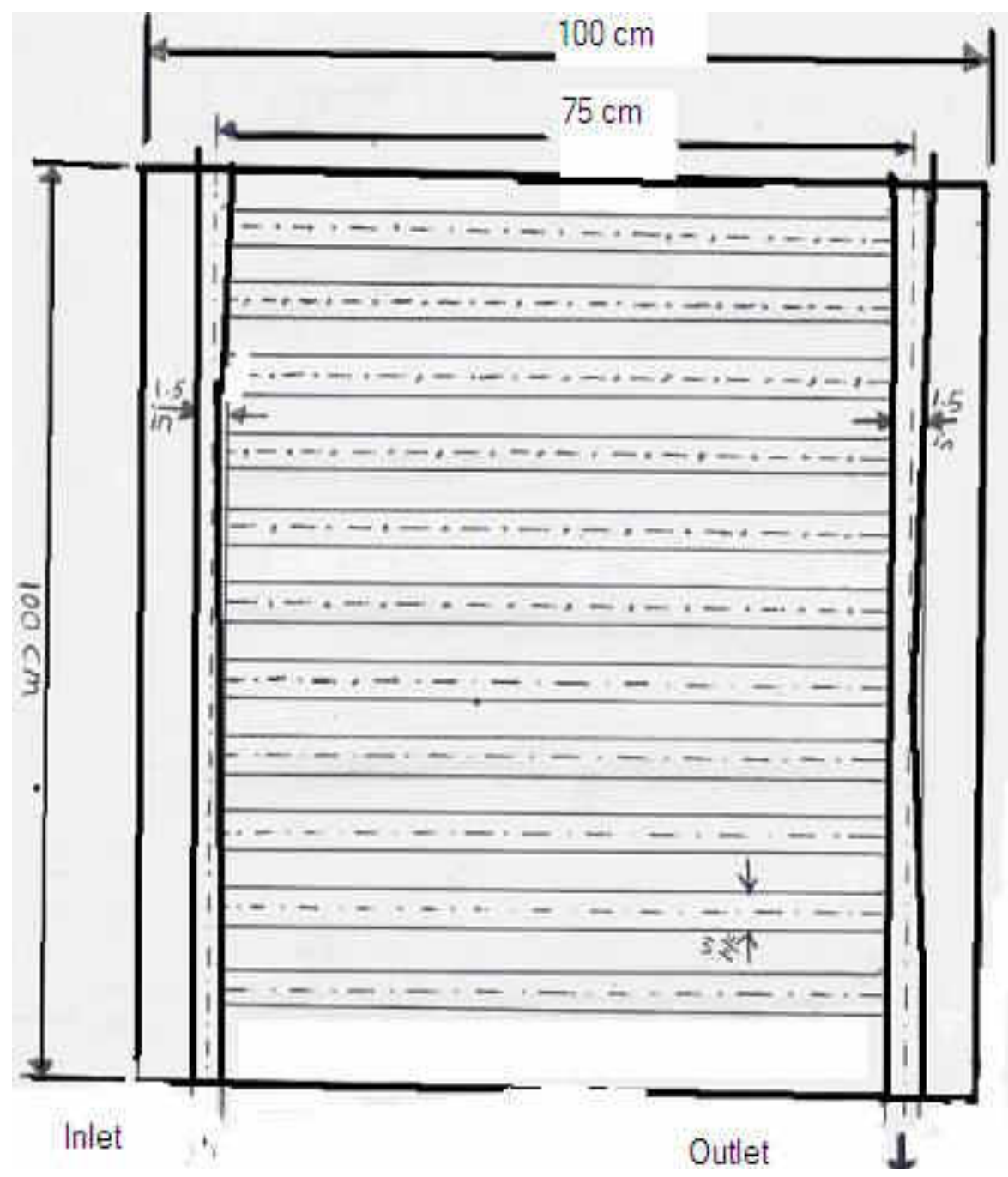

Figure 9: Water tube network.

2) kind of material : steel (cover and frame)

$>$ The furnace after manufacturing and design is shown in figure 10 . 


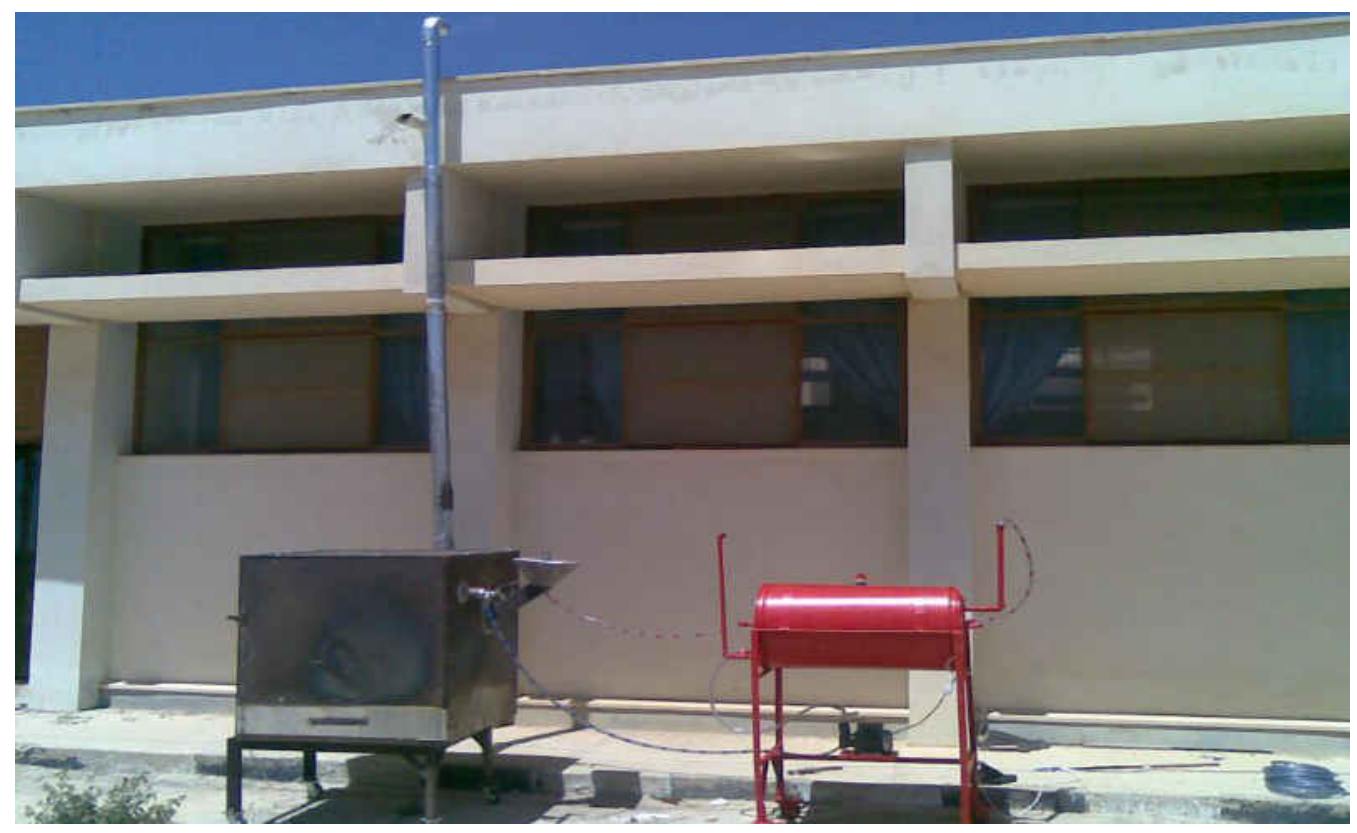

Figure 10: the furnace after built and manufactured

\section{RESULTS AND DISCUSSION:}

\section{Temperature Measurement}

Tubes are mounted on the flame combustor tube through the water jacket in three different location of the combustor rig, the first tubes are located at $12.5 \mathrm{~cm}$ from the nozzle tip, it was used to measure the temperature distribution along the vertical axis of the flame, the second tube located at $37.5 \mathrm{~cm}$ from the nozzle tip, it was used to measure the temperature along the axis of the flame, and the third tube located at 37.5 $\mathrm{cm}$ from the nozzle tip in a vertical U-tube, for gas sampling.

Five Chromel-Alumel thermocouples were used to measure the temperature of the flame along the axis of the nozzle tip, while the number of thermocouples used to measure the temperature of the flame along the vertical of the nozzle tip were four. These thermocouples are distributed uniformly at equal spaces.

The thermocouples are externally connected to digital microprocessor to read the flame temperature directly. Tables (3-5) show the oil shale reading (temperature, gas emissions). While figures 19, 20 show the Figure 10: relation between temperature \& air-fuel ratio.

Table 3: Oil shale reading

\begin{tabular}{|c|c|c|c|c|}
\hline $\begin{array}{l}\text { Mass flow } \\
\text { rate }(\mathrm{kg} / \mathrm{s})\end{array}$ & $\begin{array}{l}\text { Time } \\
(\mathrm{min})\end{array}$ & $\begin{array}{l}\text { Temperature } \\
\text { Water in } \mathrm{C}^{\mathrm{o}}\end{array}$ & $\begin{array}{l}\text { Temperature } \\
\text { Water out } C^{\mathrm{O}}\end{array}$ & $\begin{array}{l}\text { Temperature } \\
\text { Furnace } \mathrm{C}^{\mathrm{O}}\end{array}$ \\
\hline 0.003 & 15 & 20 & 49 & 396 \\
\hline 0.003 & 15 & 33 & 62 & 470 \\
\hline 0.003 & 15 & 41 & 86 & 581 \\
\hline 0.003 & 15 & 71 & 95 & 650 \\
\hline
\end{tabular}


Table 4: Oil shale reading

\begin{tabular}{|c|c|c|c|c|}
\hline $\begin{array}{c}\text { Mass flow } \\
\text { rate }(\mathrm{kg} / \mathrm{s})\end{array}$ & $\begin{array}{c}\text { Time } \\
(\mathrm{min})\end{array}$ & $\begin{array}{c}\text { Temperature } \\
\text { Water in } \mathrm{C}^{\mathrm{o}}\end{array}$ & $\begin{array}{c}\text { Temperature } \\
\text { Water out } \mathrm{C}^{\mathrm{o}}\end{array}$ & $\begin{array}{c}\text { Temperature } \\
\text { Furnace } \mathrm{C}^{\mathrm{o}}\end{array}$ \\
\hline 0.003 & 15 & 20 & 31 & 236 \\
\hline 0.003 & 15 & 25 & 43 & 316 \\
\hline 0.003 & 15 & 37 & 74 & 570 \\
\hline 0.003 & 15 & 65 & 82 & 640 \\
\hline
\end{tabular}

Table 5: Oil shale reading

\begin{tabular}{|c|c|c|c|c|}
\hline $\begin{array}{l}\text { Mass flow } \\
\text { rate }(\mathrm{kg} / \mathrm{s})\end{array}$ & $\begin{array}{l}\text { Time } \\
\text { (min) }\end{array}$ & $\begin{array}{l}\text { Temperature } \\
\text { Water in } C^{\circ}\end{array}$ & $\begin{array}{l}\text { Temperature } \\
\text { Water out } C^{\circ}\end{array}$ & $\begin{array}{l}\text { Temperature } \\
\text { Furnace } C^{\circ}\end{array}$ \\
\hline 0.003 & 15 & 20 & 46 & 390 \\
\hline 0.003 & 15 & 35 & 67 & 475 \\
\hline 0.003 & 15 & 60 & 88 & 573 \\
\hline 0.003 & 15 & 74 & 98 & 645 \\
\hline
\end{tabular}

\section{Gas Analyses}

Figure 9 shows the gas Analyzer that used to measure gas flue emission in the furnace.
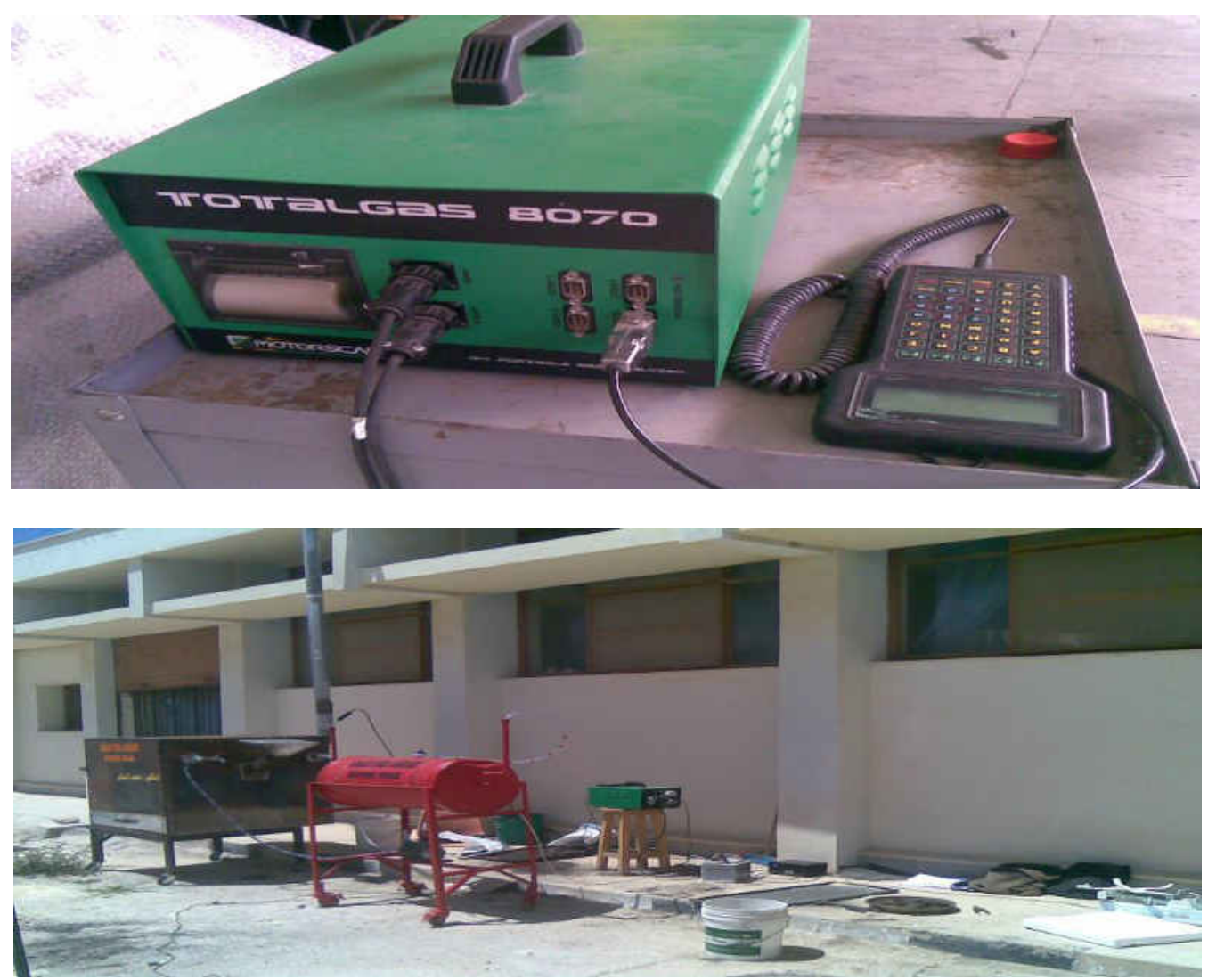

Figure 11: The Analyses gas which measure gas emission in the furnace. 
Components of Flue Gas:

The components of flue gas are listed below in the order of concentration in the gas.

1) Nitrogen $(\mathrm{N})$

2) Carbon dioxide $\left(\mathrm{CO}_{2}\right)$

3) Water vapor (Humidity).

4) Oxygen $(\mathrm{O})$

5) Carbon monoxide (CO)

6) Nitrogen oxides (NO)

7) Sulfur dioxide (SO)

8) Unburned Hydrocarbons (HC)

Table 6 show the flue gaseous which measured by gas analyzer at different furnace temperature which shown in figure 11 .

Table 6: Emissions of oil shale at different furnace temperature

\begin{tabular}{|l|c|c|c|}
\hline & Gas Emissions & $\begin{array}{c}\text { Temperature of } \\
\text { Furnace } \\
\text { (C) }\end{array}$ & $\begin{array}{c}\text { Temperature of Chimney } \\
\text { ( C) (hole @ 2.5m in the } \\
\text { chimney ) }\end{array}$ \\
\hline CO (\%) & 0.14 & & \\
CO2 (\%) & 13.62 & & \\
HC (ppm) & 104 & 600 & 123 \\
O2 (\%) & -0.08 & & \\
NO(ppm) & 111 & & \\
COcor (\%) & 1.67 & & \\
Lambda & 0.821 & & \\
\hline CO (\%) & 0.17 & & \\
CO2 (\%) & 16.81 & & \\
HC (ppm) & 128 & & \\
O2 $(\%)$ & -0.08 & 550 & \\
NO(ppm) & 134 & & \\
COcor $(\%)$ & 2.35 & & \\
Lambda & 0.748 & & \\
\hline CO (\%) & 0.11 & & \\
CO2 (\%) & 11.43 & & \\
HC (ppm) & 97 & & \\
O2 (\%) & -0.08 & & \\
NO(ppm) & 96 & & \\
COcor (\%) & 1.122 & & \\
Lambda & 0.889 & & \\
\hline
\end{tabular}




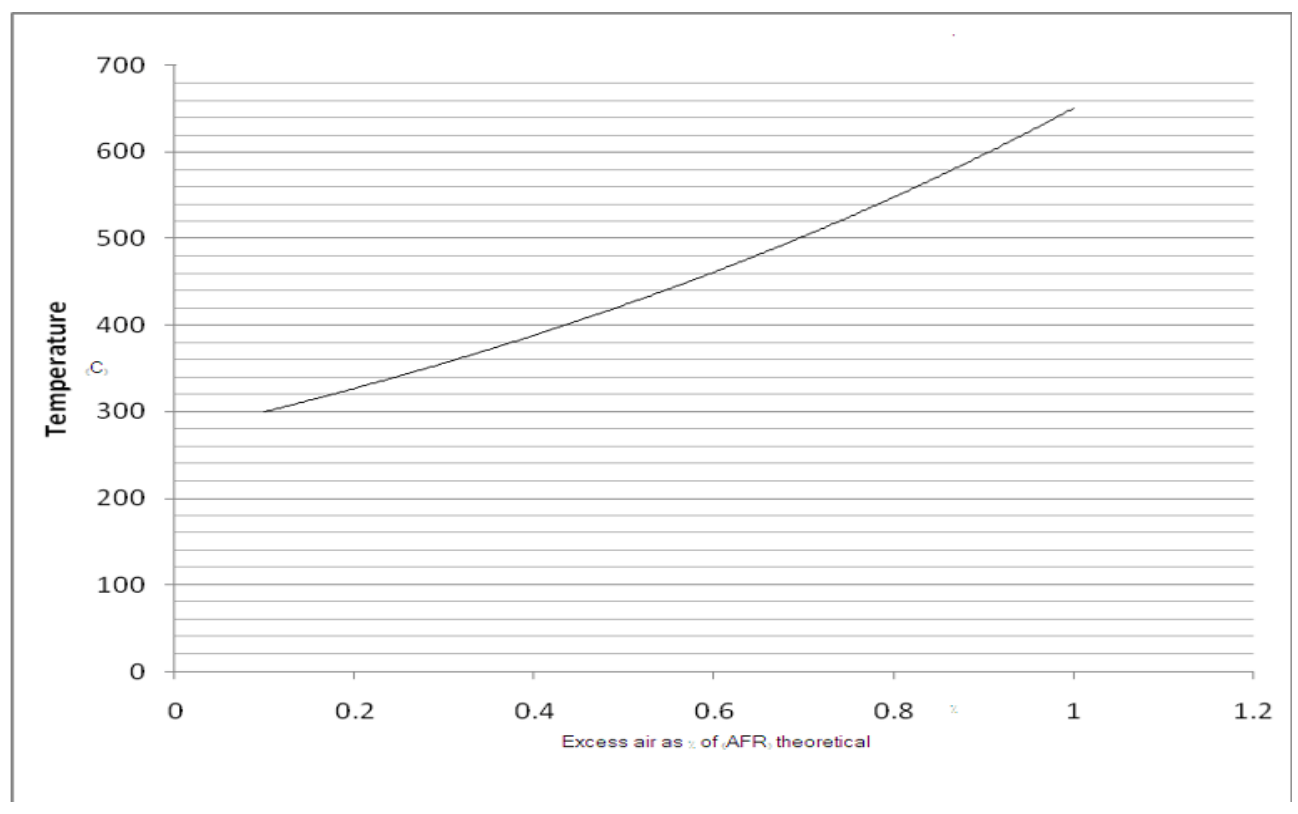

Figure 12: Temperature distribution versus excess air coefficient.

Bed temperature is firstly increased with the increase of air to fuel ratio but at higher values of excess air the trend is inversed and the bed temperature begins to decrease. It is clearly seen that the increase of air to fuel ratio up to $48 \%$ (as percentage of theoretical air to fuel ratio) will increase the bed temperature as shown in figure 12 . This is due to the increase of air flow, and hence, oxygen gas which in turn increases the mixing of solid fuel. Consequently, the combustion intensity will increase and so the temperature of bed. However, as the air to fuel ratio becomes greater than $48 \%$, the temperature begins to decrease. The reason may be due to the additional flow of cold air which absorbs some heat from the bed. Generally, bed temperatures lie between 550-650C depending on the air to fuel ratio and fluidization conditions.

\section{CONCLUSIONS}

The following may be concluded from the present work:

1. The fluidized bed combustion of El-Sultani oil shale has been experimentally investigated.

2. The results have shown that stable oil shale combustion was sustained without external energy. Steady state combustion was ensured via constant readings of temperatures through the bed.

3. High combustion efficiencies were obtained. The combustion efficiency was increased with the increase of air to fuel ratio

4. Concentration of carbon monoxide in flue gas was decreased with the increase of air to fuel ratio, while the concentration of $\mathrm{CO}_{2}$ was increased.

5. The temperature in the boiler reached to $\left(650^{\circ} \mathrm{C}\right)$ when the oil shale is burned

6. The temperature in water storage tank reaches to $\left(95^{\circ} \mathrm{C}\right)$ 
7. The incomplete combustion loss was very low.

8. With the experimental matrix used, oil shale has almost negligible effect on the emission of carbon oxides $\left(\mathrm{CO}_{\mathrm{x}}\right)$.

9. The proportion of sulfur dioxide emitted between 10-200 ppm due to the fact that $90 \%$ of $\mathrm{SO}_{2}$ be contained through calcium carbonate.

10. The values of nitrogen monoxide between 96 to $134 \mathrm{ppm}$.

11. The carbon monoxide emission from chimney was 90 to $50 \mathrm{ppm}$.

12. The possibility of burning oil shale rock in spite of the presence of (67-77)\% ash and a high percentage of sulfur (3-4)\%.

\section{REFERENCES}

1. Jordan Electricity Authority, The Investment of Oil Shale by Direct Combustion, Report, Amman, August 1991

2. Hamarneh, Y., 1995. Oil shale origin, composition and methods of utilization. Laboratory directorate- NRA.

3. Ministry of Energy and Mineral Resources, Annual Report, Amman, Jordan, 2007.

4. Ministry of Energy and Mineral Resources, Facts and Figures Amman, Jordan, 2007.

5. Natural Resources Authority, Annual Report Amman, Jordan, 2007.

6. Department of Statistics, Annual Statistical Book, Amman, Jordan, 2007

7. Proceedings of the International Oil Shale Conference Recent Trends in Oil Shale: Research and Applications, Amman, Jordan, 2006.

8. SUNCOR Energy, Presentation about Jordanian Oil Shale Project: Conceptual Design, Amman, Jordan, March 1999.

9. Proceedings of the International Oil Shale Conference Recent Trends in Oil Shale: Research and Applications, Amman, Jordan, 2006.

10. Geology and resources of some world oil-shale deposits. Scientific Investigations Report U.S. Department of the Interior. U.S. Geological Survey.( http://pubs.usgs.gov).

11. Al-Dabbas Mohammed, Mathematical Modeling of Oil Shale Combustion in Circulating Fluidized Bed Combustor, Ph.D. Thesis, University of Jordan, Jordan 2002.

12. Al-Dabbas Mohammed, Oil Shale Combustion, M.Sc. dissertation. University of Jordan, Amman, Jordan 1992.

13. Y. Hamarnah, Oil Shale Resources Development in Jordan, updated and revised by J. Alali and S. Sawaqed, 2006, Natural Resources Authority, Amman, Jordan.

\section{Appendix}

The design of furnace must has capacity greater than or equal $(10.9 \mathrm{KW})$ to provide heat for $\left(130 \mathrm{~m}^{2}\right)$ residence area.

1) The heating load:

$\mathrm{Q}=\mathrm{U} \times \mathrm{A} \times\left(\mathrm{T}_{\mathrm{o}-} \mathrm{T}_{\mathrm{i}}\right)$ 
To find $\mathrm{U}$ :

$\mathrm{U}=\frac{1}{\frac{1}{\mathrm{~h}_{\mathrm{o}}}+\left(\frac{\mathrm{t} \times A_{o}}{\mathrm{k} \times \mathrm{A}_{\mathrm{m}}}\right)+\left(\frac{\mathrm{A}_{\mathrm{o}}}{\mathrm{h}_{\mathrm{i}} \times \mathrm{A}_{\mathrm{i}}}\right)}$

$>$ From HVAC table:

$\mathrm{k}=40\left(\mathrm{~W} / \mathrm{m} .{ }^{\circ} \mathrm{C}\right)$ for steel.

$>$ From heat transfer table:

$\mathrm{h}_{\mathrm{i}}$ for water at $80{ }^{\circ} \mathrm{C}=3700\left(\mathrm{~W} / \mathrm{m}^{2} .{ }^{\circ} \mathrm{C}\right)$

$\mathrm{h}_{\mathrm{o}}$ for gas at $650{ }^{\circ} \mathrm{C}=1900\left(\mathrm{~W} / \mathrm{m}^{2} .{ }^{\circ} \mathrm{C}\right)$

$>$ Taking

$$
\begin{gathered}
\mathrm{T}_{\mathrm{o}}=95^{\circ} \mathrm{C} \\
\mathrm{T}_{\mathrm{i}}=20^{\circ} \mathrm{C} \\
\mathrm{t}=5^{*} 10^{-3}(\mathrm{~m}) \\
\mathrm{A}_{\mathrm{o}}=0.8\left(\mathrm{~m}^{2}\right) \\
\mathrm{A}_{\mathrm{i}}=0.129\left(\mathrm{~m}^{2}\right) \\
\mathrm{U}=\frac{1}{\left(2.7 \times 10^{-4}\right)+\left(2.15 \times 10^{-4}\right)+\left(3.26 \times 10^{-3}\right)}=267.022\left(\mathrm{~W} / \mathrm{m}^{2} \cdot \mathrm{C}^{\circ}\right)
\end{gathered}
$$

$>$ So the heating load:

$\mathrm{Q}=(267.02) \times(0.8) \times(60)=12.81 \mathrm{KW}$

2) furnace chimney:

The value of the chimney cross-sectional area A, depends on the boiler capacity and its height, it is calculate by using the following relation:

$$
A_{c}=\frac{m_{g a s}}{\rho v}
$$

To calculate $\dot{m}_{\mathrm{g}}$ :

$\dot{m}_{\text {sf }}=(3 \mathrm{~kg}) /\left(15^{*} 60 \mathrm{~s}\right)=0.003 \mathrm{~kg} / \mathrm{s}$

$1 \mathrm{~kg}$ solid fuel produces $38.4 \mathrm{~kg} / \mathrm{s}$ gas

$0.003 \mathrm{~kg}$ solid Fuel produce $0.1152 \mathrm{~kg} / \mathrm{s}$ gas

$\mathrm{A}_{\mathrm{c}}=(0.1152) /(1.1)(5 \mathrm{~m} / \mathrm{s})$

$\mathrm{A}_{\mathrm{c}}=0.0209 \mathrm{~m} 2$

$\mathrm{D}_{\mathrm{c}}=16.33 \mathrm{~cm}$

\section{3) Selection of circulating pump for furnace:}

$$
Q=m c_{p}\left(T-T_{i}\right), m=\frac{Q}{c_{p}\left(T-T_{i}\right)}
$$




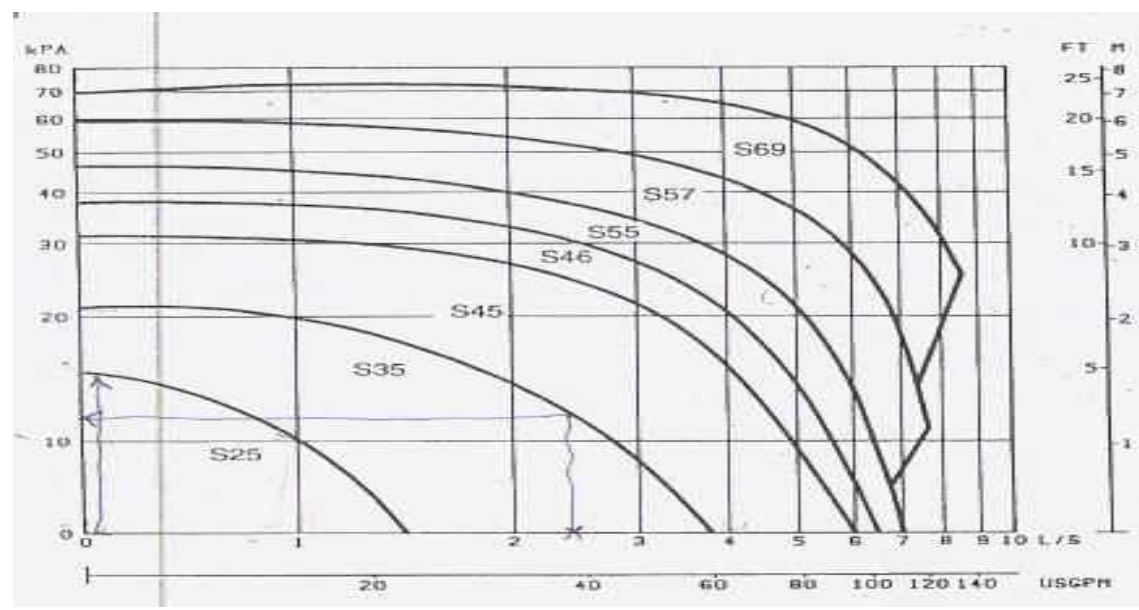

Figure13: Selection of pump.

The pressure drop per unit length:

$$
\Delta P=\frac{\Delta H}{E L}
$$

To calculate the equivalent length:

1) $2 *(\mathrm{D}=1.5$ inch, $\mathrm{L}=0.95 \mathrm{~m})$

2) $11 *(\mathrm{D}=0.75$ inch, $\mathrm{L}=0.75 \mathrm{~m})$

3) $22\left(\mathrm{~L}_{\mathrm{e}}\right.$ for $90^{\circ}$ Tee main $)$

$$
\begin{aligned}
& \sum \mathrm{L}=\{(2 * 0.95)+(11 * 0.75)\}=10.15 \mathrm{~m} \\
& \sum \mathrm{L}_{\mathrm{e}}=(22 * 1.5)=33 \mathrm{~m} \\
& \sum \mathrm{EL}=10.15+33=43.15 \mathrm{~m}
\end{aligned}
$$

$\Delta P=\frac{13000}{43.15}=301.3 \mathrm{~Pa} / \mathrm{m}$ Which is within the design range limits between (200-

550) $\mathrm{Pa} / \mathrm{m}$ as shown in figure 13. Thus, this pump is acceptable.

4) The second efficiency of water tube furnace:

The second law efficiency for devices with no work input or output such as heat exchanger where the heat is transferred from the higher temperature fluid to the lower fluid temperature.

$$
\eta=\frac{m_{1}\left(\psi_{2}-\psi_{1}\right)}{m_{21}\left(\psi_{3}-\psi_{4}\right)}
$$




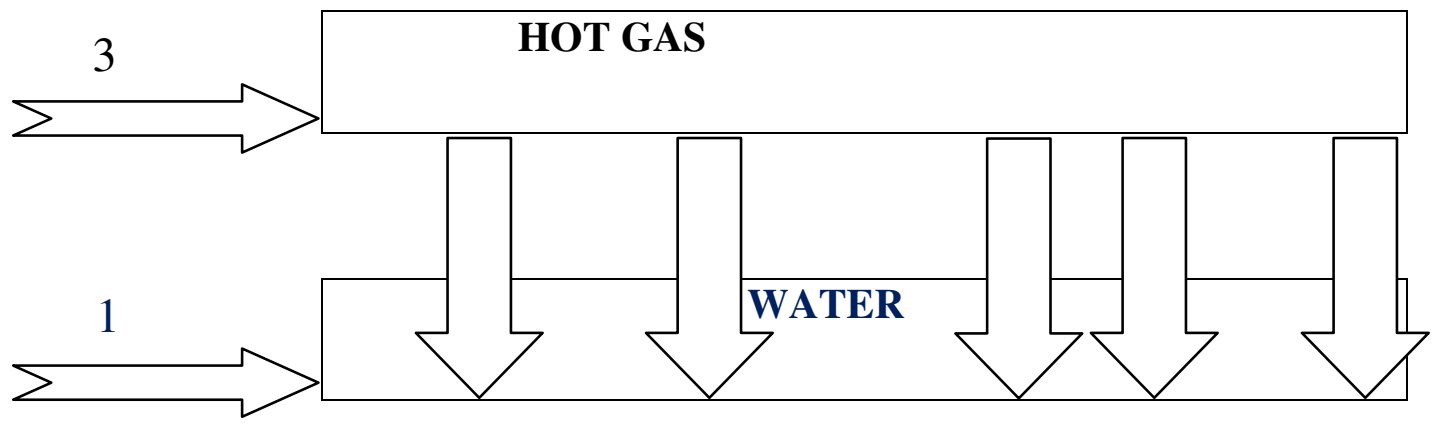

Data given:

$\dot{m}_{\mathrm{g}}=0.1152 \mathrm{Kg} / \mathrm{s}$

$m_{\text {water }}=0.0433 \mathrm{Kg} / \mathrm{s}$

$\mathrm{Cp}=1.09 \frac{K j}{K g . K}$ for flue gas

$\mathrm{T}_{0}=20 \mathrm{C}^{\mathrm{o}}$ ambient temperature

From thermo dynamics table 7:

Table 7: thermo dynamics table.

\begin{tabular}{|l|c|c|c|c|}
\hline Temperature & 20 & 95 & 650 & 190 \\
\hline enthalpy Kj/Kg & $\mathrm{h}_{1}=83.94$ & $\mathrm{~h}_{2}=397.44$ & $\mathrm{~h}_{3}=989.94$ & $\mathrm{~h}_{4}=462.34$ \\
\hline
\end{tabular}

\begin{tabular}{|c|c|}
\hline \multirow{2}{*}{$\mathrm{T}_{1}=20 \mathrm{C}^{\mathrm{o}}$} & Entropy $\mathrm{S}_{1}=0.296 \mathrm{Kj} / \mathrm{Kg} . \mathrm{k}$ \\
\cline { 2 - 2 } & Entropy $\mathrm{S}_{2}=1.25 \mathrm{Kj} / \mathrm{Kg} . \mathrm{K}$ \\
\hline
\end{tabular}

$\psi 2-\psi 1=(\mathrm{h} 2-\mathrm{h} 1)-\mathrm{T}(\mathrm{S} 2-\mathrm{S} 1)$

$=125,08 \mathrm{Kj} / \mathrm{Kg}$

$\psi 3-\psi 4=(\mathrm{h} 3-\mathrm{h} 4)-\mathrm{T}(\mathrm{S} 3-\mathrm{S} 4)$

$\frac{m(\text { prod })}{\dot{m} \text { water }}(\psi 3-\psi 4)=\frac{m(\text { prod })}{\dot{m} \text { water }}\left\{C p(T 3-T 4)-T\left(C p \ln \frac{T 3}{T 4}\right)\right.$

$\eta=\frac{125.08}{173.56}=72 \%$

5) Heat reject from solid fuel:

$\mathrm{Q}_{\mathrm{R}}=\dot{\mathrm{m}} \times \mathrm{C}_{\mathrm{v}}=0.003 \times 7327=22 \mathrm{KW}$

6) Heat added to water: 


$$
\begin{gathered}
Q_{A}=\dot{\mathrm{m}} \times\left(\mathrm{h}_{\left.\mathrm{o}, \text { at } 95 \mathrm{C}^{\circ}-\mathrm{h}_{\mathrm{i}, \text { at } 20 \mathrm{C}^{\circ}}\right)=0,0433(397.61-83.94)}\right. \\
=13.58 \mathrm{KW}
\end{gathered}
$$

\section{7) Heat loss from furnace:}

Figure 14 shows the heat loss from furnace.

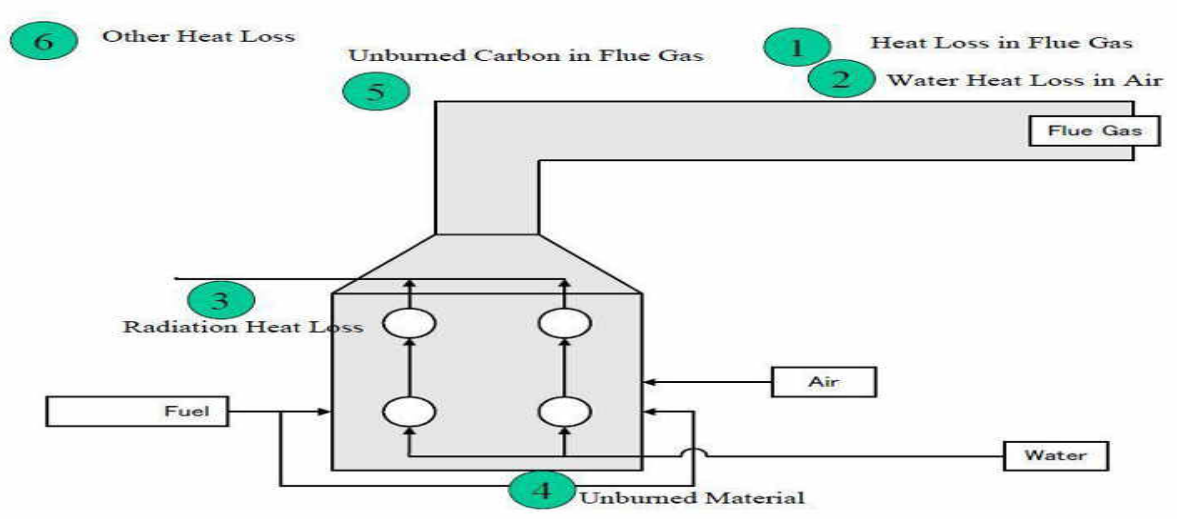

Figure 14: Heat loss from furnace.

\section{Flue gases:}

$$
\begin{aligned}
& \mathrm{Q}=\mathrm{k} \times \frac{\mathrm{T}_{\mathrm{o}}-\mathrm{T}_{\mathrm{i}}}{\mathrm{C}_{\mathrm{o}_{2}} \%} \times \mathrm{Q}_{\mathrm{i}} \\
& \mathrm{Q}=\mathbf{0 . 5 0 5 \mathrm { KW }}
\end{aligned}
$$

$\mathrm{Q}_{\mathrm{R}}$ : the load input in furnace $=22 \mathrm{KW}$

Radiation around the furnace:

\section{$Q=E \times A \times \sigma \times\left(\mathrm{T}_{\mathrm{s}}^{4}\right)$}

One side $\mathrm{A}=\mathrm{L} * \mathrm{~W}=0.95 * 0.95=0.9025 \mathrm{~m}^{2}$

All side $=6 * 0.9025=5.415 \mathrm{~m}^{2}$

$\sigma=5.67 * 10^{-8} \mathrm{w} / \mathrm{m} 2 . \mathrm{K}^{4}$

$\mathrm{T}_{\mathrm{s}}=$ absolute surface temperature of furnace $=558+273=831 \mathrm{~K}$

$Q=1 * 5.415 * 5.67 * 10^{-8 *}(831)^{4}=144.15 \mathrm{~W}$

$>$ Convection from surface around furnace:

$$
\mathrm{Q}=\mathrm{h} \times \mathrm{A} \times\left(\mathrm{h}_{\mathrm{o}}-\mathrm{h}_{\mathrm{i}}\right)
$$

Where:

A: area of surface body of furnace $=\left(5.415 \mathrm{~m}^{2}\right)$

$\mathrm{h}$ : heat transfer coefficient $=\left(15 \mathrm{~W} / \mathrm{m}^{2} \cdot \mathrm{C}^{0}\right)$

$\mathrm{T}_{\mathrm{s}}$ : surface temperature of furnace $=558 \mathrm{C}^{\circ}$.

$\mathrm{T}_{\mathrm{o}}$ : temperature of out air $=20 \mathrm{C}^{\mathrm{o}}$.

$\mathrm{Q}=5.415^{*} 15^{*}(558-20)=$ $\mathrm{Q}=43.69 \mathrm{~W}$

$>$ HEAT LOSS BY REFUSE ASH:

$$
\begin{aligned}
& \mathrm{Q}=\dot{\mathrm{m}}_{\mathrm{s}} \times \mathrm{U} \\
& \mathrm{Q}=(0.001 * 5423.212)=5.423 \mathrm{KW}
\end{aligned}
$$




\section{تصميم حارقة للصخر الزيتي للاستخدام المنزلي}

تم تصميم وبناء فرن لحرق الصخر الزيتي. حيث تم تثغيل هذا الفرن لساعات متواصلة دون حدوث مشاكل

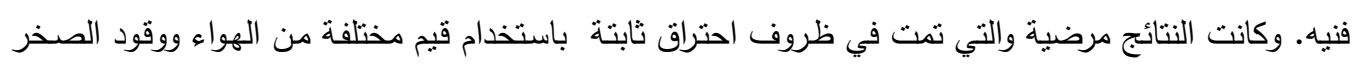
لوحظ ان كفاءة الاحتراق تزداد مع زيادة نسبة الهواء إلى الوقود وبالمقابل انخفض تركيز أول أكسيد الكربون من الغاز العادم

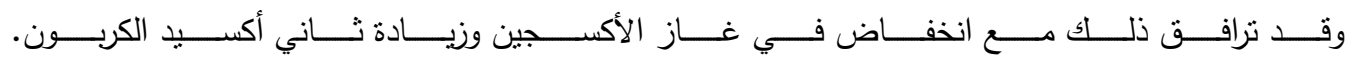

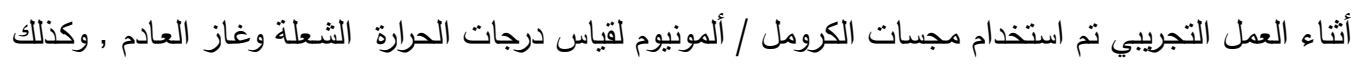

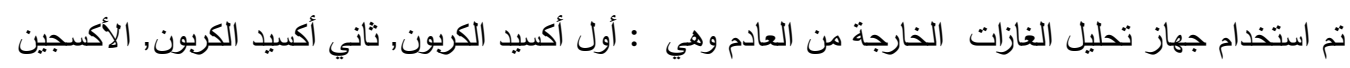

